Alexander \&. Sucluy. Ir. july $25,192.5$ with the compliments of Achene rage.

[From 'The Auk,' Vol. XXXVII, No. 1. January, 1920.]

NOTES ON SEVEN BIRDS TAKEN NEAR CHARLESTON, SOUTH CAROLINA. BY ARTHUR T. WAYNE. 


\title{
NOTES ON SEVEN BIRDS TAKEN NEAR CHARLESTON, SOUTH CAROLINA.
}

\author{
BY ARTHUR T. WAYNE.
}

THE following observations were made for the most part near my home during the late summer and early autumn of 1918, and in a radius of about two square miles. Trips were made into this area almost daily regardless of heat.

Empidonax flaviventris. YelLOW-BeluIEd Flycatcher.- Since I captured the first specimen of this bird on October 8, 1912 (Auk, XXX, 1913, 273-274), I procured an additional specimen - a young fermale on September 3, 1918. This bird was shot in an almost impenetrable jungle of elders and viburnum bushes in very low land and was feeding upon the berries of the latter bushes in company with a few Alder Flycatchers (Empidonax traillii alnorum).

Among the hundreds, I may say thousands, of Green-crested Flycatchers (Empidonax virescens) that I have closely observed during the seasons of migration in South Carolina, Georgia and Florida, hoping to detect $E$. flaviventris among them, the two birds above mentioned are the only ones I have ever seen or taken during the past thirty-five years of almost uninterrupted collecting and close observations of birds. The Yellow-bellied Flycatcher is a very rare bird in the South Atlantic States.

Progne subis subis. PURPLe Martin.-During the early spring of 1917 - the month of March, I think - an albinistic male bird of this species made its appearance at a martin house of my neighbor, about a mile away from my colony of martins, and raised its brood of young. The following year the same bird arrived sometime in the latter portion of February, and it could be noticed at a glance that there was very much more white in its plumage than during the previous year. This bird paid several visits to my martin house and I was in hopes it would mate with one of my birds and breed, but in this I was hoping against hope, because a bird goes back to its ancestral home and cannot be localized, except from the egg. This beautiful bird mated, and its mate was setting on a full complement of eggs, when on the morning of May 1, 1918, the male was picked up dead at the foot of the martin house and sent to me by Mrs. Isaac Auld. Upon preparing the specimen I could find no signs of disease nor were there any shot holes in the bird, the plumage being perfect and not a feather awry, besides it was exceedingly obese.

Although Purple Martins almost invariably arrive in the vicinity of Charleston between February 16 and 22, nest building rarely begins before the end of April. 
Dendroica cærulescens cærulescens. Black-throated BLUE WARBLER.- On August 30, 1918, I saw a bird of this species and, as it was the earliest date on which I had ever seen one in the autumnal migration, determined to obtain it, as the earliest previous records were September 15,1884 , September 13,1888 , and September 13, 1912. Upon securing the specimen, which is a young male, I was surprised to find upon examination a post ocular streak of pure white on each side of head as well as the same color in the loral regions. This discovery led me to procure a few more with the hope of finding others marked in a like manner. On September 21, I shot two young males and on October 7, I again shot another young male. These two birds are similarly marked as in the August 30 specimen although not as pronounced.

The specimen taken October 7, has the white markings confined to the loral and post ocular areas, but there is a white patch on the lower eyelids, which is absent in the other specimens. Upon examining my series of these birds, many of which were taken before 1889 , I could find no trace of the peculiarities mentioned above in either adult or young males.

Dendroica cærulescens cairnsi. CaIrns's WARBLER.- I shot on October 2, 1918, a specimen of this race which has fourteen tail feathers. I have been counting the rectrices of passerine birds ever since 1887 and the number of tail feathers in the Warblers invariably numbered twelve, therefore this bird is a novelty.

Seiurus noveboracensis notabilis. Grinnell's Water-Thrush.On July 29, 1912, I shot an adult male of this form which has the three outer rectrices on each side narrowly margined terminally on the inner webs with white; I also have a male taken on May 6, 1915, marked in a similar manner, and on August 16, 1918, I took an adult male with two outer tail feathers on each side widely margined terminally, and on the inner webs, with white. Occasional specimens of the Louisiana WaterThrush (Seiurus motacilla) possess this peculiarity as I have already pointed out (Auk, XXVIII, 1911, 488). I have two specimens marked as above.

Grinnell's Water-Thrush is the prevailing form found here, typical noveboracensis being a rara avis during both migrations. On one occasion during a heavy rain storm one night in September - I think on September 12, 1912 - I saw vast hosts of Water-Thrushes in a swamp near my house on the morning of that day, there being in sight hundreds in the area of a hundred square feet, and I estimated that there must have been certainly twenty-five thousand or even more birds in the portion of the swamp I explored that day, being in water most of the time up to my waist.

Oporornis formosus. Kentucky Warbler.- I shot on August 14, 1918 , a young male of this lovely bird which has thirteen rectrices. The day on which this bird was taken the thermometer registered in the shade $101^{\circ}$ which shows, as I pointed out in 'Birds of South Carolina,' that it migrates during the hottest portion of the summer.

Mimus polyglottos polyglottos. MockINGBIRD.-Towards sunset 
on September 19, 1918, my wife called my attention to an albino of this bird at our gate and upon my seeing it I went for my gun to procure it, as it was the first perfect albino, of a Mockingbird, I had ever seen alive in my life. Just as soon as the bird observed my intentions, it at once became exceedingly shy and although I followed it until long after sunset I could not even get within range of it at any time. I, however, saw it go to roost in a thick live oak tree in our yard among about eight or ten more birds of the same species; I then set the alarm clock to go off before sunrise hoping to secure it in the morning, which I did, shooting it from one of our fig trees. The specimen is a young male of the year which was undoubtedly raised in our yard, but escaped my notice. It is entirely white with an ashy tinge to all the feathers, and was in moult, the new feathers being pure white.

I have invariably found albinos or albinistic specimens of birds exceedingly shy, this is not because the desire of possession is very keen with the collector, but because albinos are naturally shy. This is the first Mockingbird I have shot since 1879 or 1880 , when I collected several for my late friend Dr. Gabriel E. Manigault, to form a group representing Audubon's plate for the Charleston College Museum.

Mt. Pleasant, S. C. 